University of Nebraska - Lincoln

DigitalCommons@University of Nebraska - Lincoln

10-1992

\title{
Dynamics of the Parasite Assemblage of Pimephales promelas in Nebraska
}

\author{
Mary Ann McDowell \\ University of Notre Dame, mcdowell.11@nd.edu \\ Michael T. Ferdig \\ University of Notre Dame, Michael.T.Ferdig.1@nd.edu \\ John J. Janovy Jr. \\ University of Nebraska - Lincoln, jjanovy1@unl.edu
}

Follow this and additional works at: https://digitalcommons.unl.edu/bioscijanovy

Part of the Parasitology Commons

McDowell, Mary Ann; Ferdig, Michael T.; and Janovy, John J. Jr., "Dynamics of the Parasite Assemblage of Pimephales promelas in Nebraska" (1992). John Janovy Publications. 44.

https://digitalcommons.unl.edu/bioscijanovy/44

This Article is brought to you for free and open access by the Papers in the Biological Sciences at DigitalCommons@University of Nebraska - Lincoln. It has been accepted for inclusion in John Janovy Publications by an authorized administrator of DigitalCommons@University of Nebraska - Lincoln. 


\title{
DYNAMICS OF THE PARASITE ASSEMBLAGE OF PIMEPHALES PROMELAS IN NEBRASKA
}

\author{
Mary Ann McDowell*, M. T. Ferdig†, and J. Janovy, Jr. \\ School of Biological Sciences, University of Nebraska-Lincoln, Lincoln, Nebraska 68588-0118
}

\begin{abstract}
Present theory states that in species-poor assemblages interactions among species are negligible and assemblage structure is a result of host/parasite interactions. A corollary to this theory is that parasite species assemblages should behave as accumulations of multiple-kind items drawn from a population in which only the relative probability of drawing each kind varies. This study was designed to test this prediction by comparing descriptor values, including diversity indices, species density values, equitability, and prevalence to those obtained from data produced by a Monte Carlo simulation model. The parasite assemblage consisted of 7 parasite species or types found in the fathead minnow, Pimephales promelas. The data presented indicate that all of the assemblage descriptors are positively intercorrelated, as in the Monte Carlo simulations. Also, the field data are described best by a model in which a single population structuring mechanism operates, suggesting that aggregating mechanisms are environmental in origin and act on all parasite populations more or less uniformly. In addition, the $P$. promelas assemblage structure appears to be a function of current year streamflow, suggesting that abiotic factors influence parasite assemblage structure through effects on individual parasite species' probability of infection.
\end{abstract}

A major question in parasite ecology concerns the interactive or noninteractive nature of parasite species assemblages (Holmes, 1961; Hair and Holmes, 1975; Price, 1980; Bush and Holmes, 1986; Hoberg, 1986; Kennedy et al., 1986). Proponents of the role of interaction in structuring parasite communities tend to study rich intestinal faunas and interpret their results in terms of interactions described for free-living communities. Those working with species-poor assemblages, however, tend to find little evidence of interactions in such assemblages (Kennedy et al., 1986; Janovy and Hardin, 1988). In speciespoor assemblages, interactions among species are considered negligible and assemblage structure is attributed to host/parasite interactions, in a manner consistent with the prediction of Price $(1980,1984)$. A corollary to this theory is that parasite species assemblages should behave as accumulations of multiple-kind items drawn from a population in which only the relative probability of drawing each kind varies.

Janovy and Hardin $(1987,1988)$ studied a relatively impoverished assemblage of fish parasite species. The study described an assemblage of 7 parasites in the plains killifish Fundulus $z e$ -

Received 28 May 1991; revised 6 May 1992; accepted 22 May 1992.

* Present address: Department of Medical Microbiology and Immunology, University of WisconsinMadison, Madison, Wisconsin 53706.

$\dagger$ Present address: Department of Veterinary Science, University of Wisconsin-Madison, Madison, Wisconsin 53706 . brinus. The samples were collected over a 5-yr period from a braided river in which streamflow fluctuated. The results from these 2 studies suggest that the abiotic conditions, primarily previous year's streamflow, influenced the probabilities of infection with the different parasite species. It has been proposed further that the $F$. zebrinus system behaves as a Monte Carlo model in which parasites are drawn at random from a supraassemblage (i.e., environment) of infective stages (Janovy et al., 1990). The present study is an attempt to test the predictions of Janovy and Hardin (1988) and Janovy et al. (1990) by extending the work to a different host species. The host species, the minnow Pimephales promelas, was chosen for study because it has a geographical distribution much broader, and an ecological distribution narrower, than that of plains killifish (Pflieger, 1975).

The parasite system studied consisted of 7 parasite species or types that exhibited a variety of life cycles. These parasites were Trichodina sp. (Ciliophora: Peritrichia), gill surface; Myxosoma funduli Kudo, 1918 (Myxozoa: Myxosporea), gill tissue; Dactylogyrus bychowski Mizelle, 1937 (Monogenea), gill surface; Gyrodactylus hoffmani Welborn and Rogers, 1967 (Monogenea), body surface, mainly fins; Gyrodactylus sp. (Monogenea), gill surface; Neascus sp. (Digenea: Posthodiplostomum), eye; Neascus sp. (Digenea: Posthodiplostomum), body cavity. The eye and the body cavity of minnows present 2 very different habitats, therefore it is possible that the 2 Neascus forms have different effects on host biology. Because of this possibility, the 2 larval 
TABLE I. Collection dates and sample sizes for $P i$ mephales promelas.

\begin{tabular}{|c|c|c|c|c|}
\hline Site & $\begin{array}{l}\text { Date } \\
1988\end{array}$ & $\begin{array}{c}\text { Sample } \\
\text { size }\end{array}$ & $\begin{array}{l}\text { Date } \\
1989\end{array}$ & $\begin{array}{c}\text { Sample } \\
\text { size }\end{array}$ \\
\hline \multirow[t]{5}{*}{ Brule } & 22 June & 16 & 26 March & 16 \\
\hline & & & 15 May & 16 \\
\hline & & & 26 June & 16 \\
\hline & & & 13 August & 16 \\
\hline & & & 5 October & 16 \\
\hline \multirow[t]{5}{*}{ Roscoe } & 1 June & 20 & $26 \mathrm{March}$ & 16 \\
\hline & 22 June & 16 & 14 May & 16 \\
\hline & & & 24 June & 16 \\
\hline & & & 14 August & 16 \\
\hline & & & 5 October & 16 \\
\hline \multirow[t]{5}{*}{ Paxton } & 5 July & 16 & 26 March & 12 \\
\hline & 31 July & 16 & 16 May & 16 \\
\hline & 13 August & 17 & 27 June & 16 \\
\hline & & & 2 September & 16 \\
\hline & & & 5 October & 16 \\
\hline \multirow[t]{5}{*}{ Sutherland } & 6 July & 16 & $26 \mathrm{March}$ & 16 \\
\hline & 31 July & 16 & 16 May & 16 \\
\hline & 13 August & 17 & 17 July & 13 \\
\hline & & & 2 September & 9 \\
\hline & & & 5 October & 16 \\
\hline
\end{tabular}

trematodes were treated as separate types in the results and discussion sections.

With respect to the above system the following questions were addressed:

(1) Do assemblages of parasites behave as collections of multiple kind independent sampling events in which only the relative probability of infection varies?

(2) When statistically significant positive associations occur between parasite species, both in prevalence and density, can the associations be explained best by ecological cooccurrence between infective stages?

(3) Does the assemblage structure tend to be a function of previous year abiotic conditions?

\section{MATERIALS AND METHODS}

In the present study, samples were taken from 4 sites, 2 in the South Platte River, and 2 in the North Platte River. These 2 rivers differ both ecologically and in terms of their geological history (Bentall, 1975). The South Platte River is a typical braided plains river. Snow melt is the main source of water and in the summer the depth rarely exceeds $50 \mathrm{~cm}$, except in holes around bridges and debris. The North Platte River differs mainly in that the water flow is controlled by humans. The amount of flow fluctuates greatly and often in the course of a summer. During low water times, the physical attributes of the North Platte resemble those of the South Platte River. High discharge rates change the structure of the river dramatically; during those weeks the average depth can reach up to $150 \mathrm{~cm}$ and up to $400 \mathrm{~cm}$ in piling holes. Samples were taken from the South Platte River from a 1.0-km reach at Brule, Nebraska, and from a $2.0-\mathrm{km}$ reach $5.0 \mathrm{~km}$
TABLE II. Streamflow during the study period.

\begin{tabular}{|c|c|c|c|}
\hline & & \multicolumn{2}{|c|}{$\begin{array}{l}\text { Average annual daily discharge rates } \\
\qquad\left(\mathrm{m}^{3} / \mathrm{sec}\right)\end{array}$} \\
\hline & & Calendar year & Water year* \\
\hline \multirow[t]{2}{*}{1987} & North Platte & 8.5 & 16.1 \\
\hline & South Platte & 18.4 & 20.3 \\
\hline \multirow[t]{2}{*}{1988} & North Platte & 9.6 & 9.7 \\
\hline & South Platte & 10.6 & 10.6 \\
\hline \multirow[t]{2}{*}{1989} & North Platte & 8.6 & 8.6 \\
\hline & South Platte & 5.5 & 5.9 \\
\hline
\end{tabular}

* Water years run from 1 October through 30 September. For example. water year 1988 begins October 1987 and ends September 1988.

east of Roscoe, Nebraska. Samples were taken from the North Platte River from a $0.5-\mathrm{km}$ reach, including a connecting pond, at Paxton, Nebraska, and from a $0.5-\mathrm{km}$ reach, including a connecting stream, at Sutherland, Nebraska.

Pimephales promelas samples were collected by seining. Fish were examined at the Cedar Point Biological Station, $13 \mathrm{~km}$ north of Ogallala, Nebraska, in the summer and at the University of Nebraska-Lincoln in the early spring and fall. Twenty-nine samples containing a total of 456 fish were collected over a $2-y r$ period. Collection sites, dates, and sample sizes are given in Table I. Sample sizes were determined either by the number captured or by the number that could be examined within a $72-\mathrm{hr}$ period. Fluctuating streamflow did not always allow for scheduled collections of equal sample sizes; however, an attempt was made to space the collections over the year to account for seasonal differences and to collect from the 4 sites within 3 wk of each other.

Each fish was measured $(\mathrm{cm})$ and the gill arches were excised. Gill bars were laid anterior (outside) face up in sequence on a microscope slide. A coverslip was added and the fresh preparation examined under $100 \times$ magnification for the presence of parasites. The parasites were identified and counted. The gills then were turned over, the posterior (inside) face examined, and counts and measurements recorded as described. The body and eyes of the fish were then dissected and the parasites found also were identified and counted.

Discharge rates of the North and South Platte rivers were obtained from the Nebraska Department of Water Resources for gauging stations closest to the areas of study. Records for the North Platte River were obtained from the Sutherland station, reference \#06691000. The station at North Platte, Nebraska, reference \#06765500, was the source of the streamflow records for the South Platte River. The data are summarized for water years (1 October-30 September) and for calendar years. The data for the 1988 and 1989 water and calendar years are summarized in Table II.

Five numerical descriptors were used to characterize the parasite species assemblages. Diversity was expressed by the Shannon $\mathrm{H}^{\prime}$ index, calculated using $\log$ $p_{i j}$ at 2 levels, the individual host, or infraassemblage, level ( $\left.\mathrm{H}^{\prime} \mathrm{IA}\right)$ and at the host population level, or sample assemblage level $\left(\mathrm{H}^{\prime} \mathrm{SA}\right) . \mathrm{H}^{\prime} \mathrm{SA}$ is the diversity index of an assemblage of parasite species in a sample of host individuals and should be considered an estimate, from one sample, of what the ecologists term "component 
TABLE III. Order of abundance, relative abundance, and Lorenz equitability for species in the parasite assemblage of Pimephales promelas.

\begin{tabular}{|c|c|c|c|c|c|c|c|c|}
\hline \multirow{2}{*}{$\frac{\begin{array}{c}\text { Circum- } \\
\text { stance }\end{array}}{\text { Combined }}$} & \multicolumn{7}{|c|}{ Parasites in order of abundance (relative abundance)* } & \multirow{2}{*}{$\begin{array}{l}\begin{array}{c}\text { Loren } \\
\text { equit- } \\
\text { ability }\end{array} \\
0.394\end{array}$} \\
\hline & $\begin{array}{c}\text { BC } \\
(0.478)\end{array}$ & $\begin{array}{c}\mathrm{T} \\
(0.324)\end{array}$ & $\begin{array}{c}\mathrm{D} \\
(0.093)\end{array}$ & $\begin{array}{c}\mathrm{M} \\
(0.028)\end{array}$ & $\begin{array}{c}\text { BS } \\
(0.028)\end{array}$ & $\begin{array}{c}E \\
(0.005)\end{array}$ & $\begin{array}{c}\stackrel{G}{G} \\
(0.005)\end{array}$ & \\
\hline Sutherland & $\begin{array}{c}\text { BC } \\
(0.624)\end{array}$ & $\begin{array}{c}\mathrm{M} \\
(0.133)\end{array}$ & $\begin{array}{c}\mathrm{D} \\
(0.118)\end{array}$ & $\begin{array}{c}\mathrm{T} \\
(0.101)\end{array}$ & $\begin{array}{c}\text { BS } \\
(0.013)\end{array}$ & $\begin{array}{c}E \\
(0.010)\end{array}$ & $\begin{array}{c}\text { G } \\
(0.001)\end{array}$ & 0.366 \\
\hline Paxton & $\begin{array}{c}\mathrm{T} \\
(0.397)\end{array}$ & $\begin{array}{c}\text { BC } \\
(0.387)\end{array}$ & $\begin{array}{c}\text { D } \\
(0.132)\end{array}$ & $\begin{array}{c}\mathrm{M} \\
(0.057)\end{array}$ & $\begin{array}{c}\text { BS } \\
(0.016)\end{array}$ & $\begin{array}{c}E \\
(0.009)\end{array}$ & $\begin{array}{c}\mathrm{G} \\
(0.002)\end{array}$ & 0.412 \\
\hline Roscoe & $\begin{array}{c}\mathrm{T} \\
(0.475)\end{array}$ & $\begin{array}{c}\text { BC } \\
(0.375)\end{array}$ & $\begin{array}{c}\mathrm{D} \\
(0.067)\end{array}$ & $\begin{array}{c}\text { M } \\
(0.058)\end{array}$ & $\begin{array}{c}\text { BS } \\
(0.014)\end{array}$ & $\begin{array}{c}\mathrm{G} \\
(0.010)\end{array}$ & $\begin{array}{c}E \\
(0.001)\end{array}$ & 0.343 \\
\hline Brule & $\begin{array}{c}\text { BC } \\
(0.531)\end{array}$ & $\begin{array}{c}\mathrm{T} \\
(0.304)\end{array}$ & $\begin{array}{c}\text { BS } \\
(0.071)\end{array}$ & $\begin{array}{c}\text { D } \\
(0.065)\end{array}$ & $\begin{array}{c}\mathbf{M} \\
(0.021)\end{array}$ & $\begin{array}{c}\mathrm{G} \\
(0.005)\end{array}$ & $\begin{array}{c}E \\
(0.003)\end{array}$ & 0.363 \\
\hline 1988 & $\begin{array}{c}\text { BC } \\
(0.591)\end{array}$ & $\begin{array}{c}\mathrm{M} \\
(0.202)\end{array}$ & $\begin{array}{c}\text { D } \\
(0.167)\end{array}$ & $\begin{array}{c}\mathrm{T} \\
(0.016)\end{array}$ & $\begin{array}{c}G \\
(0.013)\end{array}$ & $\begin{array}{c}E \\
(0.010)\end{array}$ & $\begin{array}{c}\text { BS } \\
(0.001)\end{array}$ & 0.341 \\
\hline 1989 & $\begin{array}{c}\text { BC } \\
(0.444)\end{array}$ & $\begin{array}{c}\mathrm{T} \\
(0.416)\end{array}$ & $\begin{array}{c}\mathrm{D} \\
(0.071)\end{array}$ & $\begin{array}{c}\text { BS } \\
(0.036)\end{array}$ & $\begin{array}{c}\mathbf{M} \\
(0.027)\end{array}$ & $\begin{array}{c}E \\
(0.004)\end{array}$ & $\begin{array}{c}\mathbf{G} \\
(0.002)\end{array}$ & 0.374 \\
\hline
\end{tabular}

* BC, body cavity Neascus; T, Trichodina sp.; D, Dactylogyrus bychowski; M, Myxosoma funduli; BS, Gyrodactylus hoffmani; E, eye Neascus; G, Gyrodactylus sp.

community." $\mathrm{H}^{\prime} \mathrm{IA}$ was calculated using minus sum $\mathrm{p}_{\mathrm{ij}}$ $\log p_{i j}$ where $p_{i j}$ is the proportion of parasite species $i$ in host individual $\mathrm{j}$. The mean $\mathrm{H}^{\prime} \mathrm{IA}$ was calculated by averaging the individual indices in a sample. $\mathrm{H}^{\prime} \mathrm{SA}$ was calculated using minus sum $p_{i k} \log p_{i k}$ where $p_{i k}$ is the proportion of species $i$ in sample $k$. Species density was taken as the mean number of parasite species or types per individual host, was calculated for each fish sample, and was the mean of the frequency distribution obtained by plotting number of individual hosts against parasite species/host classes. The prevalence of a parasite species was the number of infected individuals divided by the total number of fish in a sample. Mean prevalence was calculated by averaging all of the assemblage species' prevalences. Evenness of the parasite species representation was assessed using the Lorenz equitability index (McAuliffe, 1984).

The dynamic behavior of parasite assemblages, in fluctuating conditions, was summarized by using correlation matrices and regression lines relating species density, H'IA, H'SA, to mean prevalence, over time and space (Janovy et al., 1990). Correlations between $\mathrm{H}^{\prime} \mathrm{IA}, \mathrm{H}^{\prime} \mathrm{SA}$, and species density, Lorenz equitability, and streamflow values also were determined (Janovy and Hardin, 1988). Species density and $H^{\prime} I A$ frequency distributions were compared using $t$-test statistics. Cooccurrence of species was assessed by means of prevalence and relative density correlations. Prevalences and relative densities from all dates and sites were used to calculate the correlation coefficients for the 21 species-pair combinations.

Computer simulations were made by the use of the Monte Carlo simulation model of Janovy et al. (1990). The model used prevalences, from the field data, as probabilities of infection and placed computer parasites in an array, with each species present in proportion to its probability of infection. Each computer fish sampled the array a random number of times between 0 and 25 , accumulating parasites accordingly. The numerical descriptors were calculated for each fish and sample. A model sample consisted of 24 fish. Frequency distributions were determined for the model species density and infraassemblage diversity values. These distributions were compared to the observed distributions by the means of ANOVA.

Terminology is consistent with that recommended by Margolis et al. (1982). The average number of parasites per fish (infected + uninfected) in a sample is termed relative density (=mean).

\section{RESULTS}

\section{Assemblage diversity}

Lorenz equitabilities for each site (combined years), each year (combined sites), and overall (all years and sites combined), as well as order of abundance for the 7 parasite types, are given in Table III. Over space and time, body cavity metacercaria and Trichodina sp. were the most abundant parasites. The least abundant types were eye metacercaria and Gyrodactylus sp. and the relative positions of the other assemblage members varied according to sites and years.

Correlations between annual streamflow, mean infraassemblage diversity, sample assemblage diversity, species density, and equitability for the 29 samples are given in Table IV. In no case was the correlation coefficient between a diversity indicator value and previous calendar or water year streamflow high enough to reject the hypothesis of independence. However, species density was significantly and negatively correlated with both the current calendar and water year streamflow, although the correlation coefficient values were relatively low.

Correlations between annual streamflow and assemblage descriptors were calculated separately for the 16 samples collected from the North 
TABLE IV. Correlations between streamflow (by calendar year [CY] and water year [WY]) and sample diversity, species density, and equitability for the parasite assemblage of Pimephales promelas.

\begin{tabular}{|c|c|c|c|c|c|c|c|c|}
\hline & $\begin{array}{c}\text { CY } \\
\text { stream- } \\
\text { flow }\end{array}$ & $\begin{array}{l}\text { WY } \\
\text { stream- } \\
\text { flow }\end{array}$ & $\begin{array}{l}\text { Previous } \\
\text { CY flow }\end{array}$ & $\begin{array}{l}\text { Previous } \\
\text { WY flow }\end{array}$ & $\begin{array}{l}\text { Mean } \\
\text { H'IA }^{\prime}\end{array}$ & $\mathbf{H}^{\prime} \mathrm{SA}$ & $\begin{array}{l}\text { Species } \\
\text { density }\end{array}$ & Lorenz \\
\hline CY streamflow & 1.00 & 1.00 & 0.24 & $0.65^{*}$ & -0.24 & 0.16 & $-0.42^{*}$ & 0.19 \\
\hline WY streamflow & & 1.00 & 0.25 & $0.68^{*}$ & 0.25 & 0.14 & $-0.43^{*}$ & 0.18 \\
\hline Previous CY flow & & & 1.00 & $0.58^{*}$ & 0.00 & 0.25 & -0.08 & 0.26 \\
\hline Previous WY flow & & & & 1.00 & -0.29 & 0.03 & -0.36 & 0.07 \\
\hline Mean $H^{\prime} I A$ & & & & & 1.00 & $0.62^{*}$ & $0.92^{*}$ & $0.62^{*}$ \\
\hline $\mathrm{H}^{\prime} \mathrm{SA}$ & & & & & & 1.00 & $0.40^{*}$ & $0.97^{*}$ \\
\hline Species density & & & & & & & 1.00 & $0.47^{*}$ \\
\hline Lorenz equitability & & & & & & & & 1.00 \\
\hline
\end{tabular}

* $r$ values high enough to reject the hypothesis that $r=0$ at the $5 \%$ level with $\mathrm{n}=29$.

Platte River. None of the diversity values was significantly correlated with annual streamflow. In the 13 South Platte River samples, equitability was significantly and positively correlated with annual streamflow at the 0.05 level.

\section{Assemblage description}

Two of the 29 model species density distributions differed from the field distributions when differences were assessed by means of ANOVA (Paxton, 15 May 1989; Roscoe, 13 August 1989). However, when the computer fish were allowed to sample the parasite supraassemblage a random number of times between 0 and 50, the model and field distributions were not significantly different from one another. Sampling the supraassemblage in the above manner doubled the theoretical species density values while retaining the relationship between $\mathrm{H}^{\prime} \mathrm{IA}$ and $\mathrm{H}^{\prime} \mathrm{SA}$.

Seven of the theoretical $\mathrm{H}^{\prime} \mathrm{IA}$ distributions were significantly different from those of the field data, as indicated by ANOVA. These 7 distributions (Roscoe, 22 June 1988, 15 May 1989, 24 June 1989; Brule, 24 June 1989; Paxton, 13 August

TABLE V. Correlation coefficients between assemblage descriptors.

\begin{tabular}{lllll}
\hline & $\begin{array}{c}\text { Species } \\
\text { density }\end{array}$ & $\begin{array}{c}\text { Mean } \\
\text { H'IA }\end{array}$ & H'SA & $\begin{array}{c}\text { Mean } \\
\text { preva- } \\
\text { lence }\end{array}$ \\
\hline Field data & & & & \\
Species density & 1.00 & $0.92^{*}$ & $0.40^{*}$ & $0.97^{*}$ \\
Mean H'IA & & 1.00 & $0.62^{*}$ & $0.92^{*}$ \\
H'SA & & & 1.00 & $0.44^{*}$ \\
Mean prevalence & & & & 1.00 \\
Model data & & & & \\
Species density & 1.00 & $0.99^{*}$ & $0.88^{*}$ & $0.94^{*}$ \\
Mean H'IA & & 1.00 & $0.90^{*}$ & $0.94^{*}$ \\
H'SA & & & 1.00 & $0.89^{*}$ \\
Mean prevalence & & & & 1.00 \\
\hline
\end{tabular}

* Probability that $r=0$ is less than 0.05 with $\mathrm{n}=29$.
1989; and Sutherland, 31 July 1988, 13 August 1988) remained significantly different from those predicted by the model, when the sampling rate was doubled. Analysis of parasite species density values for each collection indicated no apparent pattern of microallopatry or intensity reduction that could account for the differences.

The dynamic behavior of the parasite assemblage, in fluctuating conditions, was summarized by using correlation matrices (Table $\mathrm{V}$ ) and regression lines (Figs. 1-3) relating species density, mean infraassemblage diversity, and sample assemblage diversity, to mean prevalence, over time and space. The correlation matrices (Table V) indicated that all of the values were significantly and positively correlated in both the field and the model data. However, the correlation coefficients between the population level descriptors and the individual level descriptors were lower in the field data than in the model data.

Figure 1 relates mean prevalence to species density for field data, represented by the solid line, and model data, represented by the dashed line. There was a positive correlation between species density and mean prevalence in both the field and the model data; in fact, the slopes of the 2 regression lines were nearly the same. The relationship between infraassemblage diversity and mean prevalence was strong in both the field and model data (Fig. 2). When sample assemblage diversity was compared to mean prevalence, there was a positive correlation for both data sets; however, the field data indicated a weaker relationship than the model predicted (Fig. 3).

\section{Cooccurrence of parasite species}

Prevalence and density values indicated few patterns of cooccurrence. The Trichodina sp. values were positively correlated with the Gyrodac- 


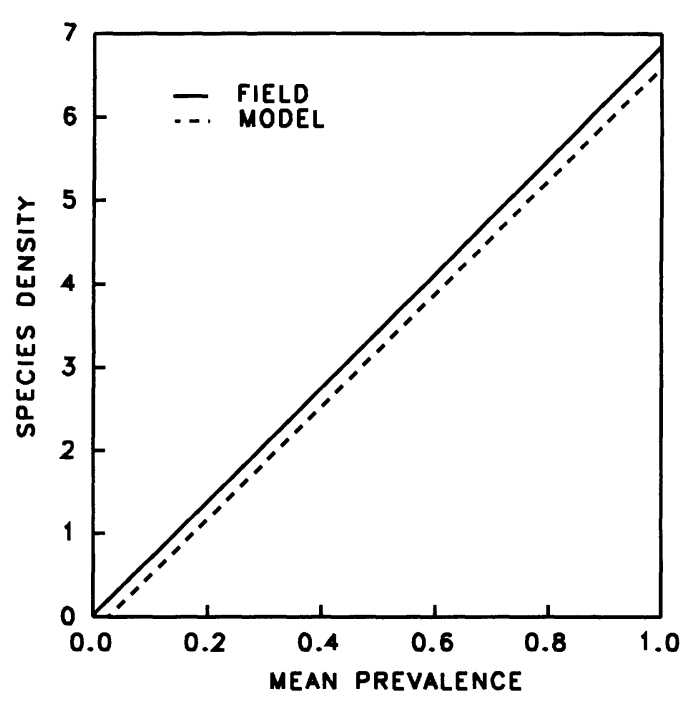

FIGURE 1. Regression lines relating species density to mean prevalence over time for both the simulation model data and the Pimephales promelas assemblage data.

tylus hoffmani prevalence and density values. Gyrodactylus sp. prevalence also was positively correlated with the Trichodina sp. prevalence; however, the prevalence correlation between the 2 Gyrodactylus species was not significantly different from zero. The correlation between the prevalence of the 2 Neascus types also was significantly different from zero. The relative densities of the two Gyrodactylus species were positively correlated. Aside from the prevalence correlations of the Gyrodactylus species with Trichodina sp., as well as the density correlation with themselves, the density correlation of Trichodina sp. and the body surface gyrodactylid, and the Neascus prevalence correlation, none of the other values was high enough to reject the independence hypothesis. Negative correlations between prevalences or relative densities were not significantly different from zero.

\section{DISCUSSION}

The results from this study are consistent with the predictions of Janovy and Hardin (1988) and Janovy et al. (1990). That is, the data presented suggest that over extended time and space this species-poor assemblage of parasites behaves as a collection of independent sampling events in which only the relative probability of infection with various parasite species varies. The correlation matrices relating the assemblage descriptors (Table $\mathrm{V}$ ) indicate that all of the values of

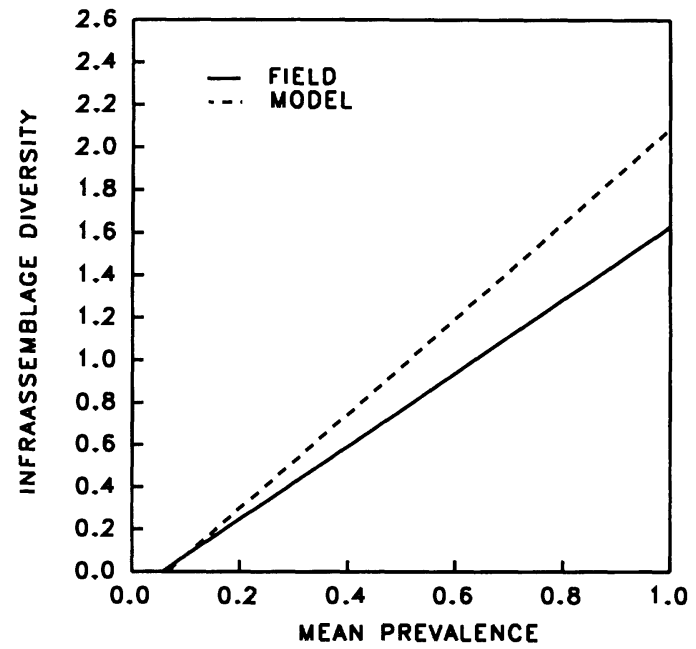

FIGURE 2. Regression lines relating infraassemblage diversity to mean prevalence over time for both the simulation model data and the Pimephales promelas assemblage data.

species density, infraassemblage diversity, sample assemblage diversity, and mean prevalence are significantly and positively correlated. However, the relationship between the sample, or population, level descriptor, and the individual host descriptors is stronger in the model data than in the field data. The relationship between sample assemblage diversity and mean prevalence was uncoupled in the Janovy et al. (1990) Monte Carlo model by introducing a variety of

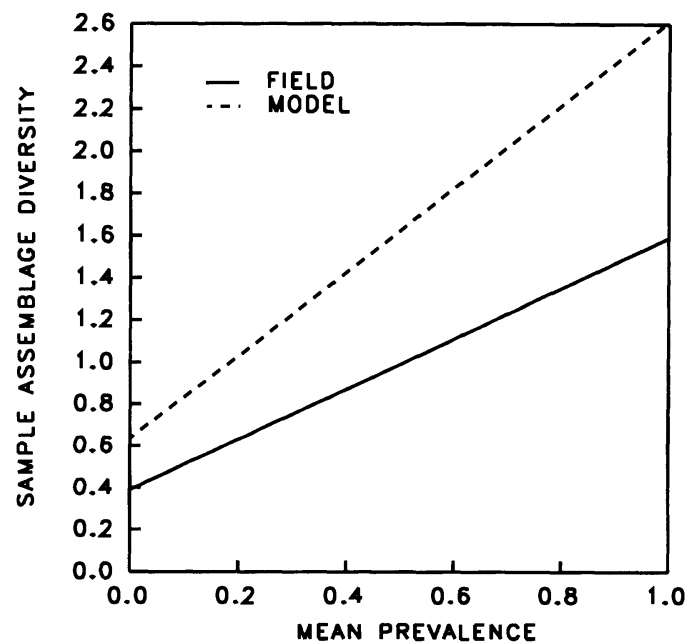

FIGURE 3. Regression lines relating sample assemblage diversity to mean prevalence over time for both the simulation model data and the Pimephales promelas assemblage data. 
structuring mechanisms for the individual parasite populations. The regression line relating sample assemblage diversity and mean prevalence acquired a negative slope when multiple population aggregating mechanisms were employed. In the present study, even though the slope of the regression line relating sample assemblage diversity and mean prevalence was lower in the field data than in the model data, the relationship still was significantly and positively correlated.

The predictions of Janovy et al. (1990) indicate an uncoupling of component community diversity ( $=\mathrm{H}^{\prime} \mathrm{SA}$ approximately) from intracommunity diversity ( $\left.\mathrm{H}^{\prime} \mathrm{IA}\right)$ and from mean prevalence, over a wide range of prevalences, when competition is introduced into the system prior to the sampling of the parasite supraassemblage by the fish. Because this uncoupling was not observed in the field data, the most appropriate interpretation of these data is that competition likely did not occur prior to the dissection and counting of parasites in the laboratory. Had it occurred in a manner that affected either numbers or presence/ absence of potential competitors, then that effect should have appeared in the figures and in Table V.

The $P$. promelas field data were best described by a model in which a single population structuring mechanism operates, suggesting that in nature, aggregating mechanisms are of environmental origin and act on all parasite species more or less uniformly. That is, the parasite populations seem to be aggregated by a similar mechanism, possibly of environmental origin. This result suggests that abiotic factors in the host's environment that influence the probability of infection may play an important role in structuring parasite species assemblages. If the abiotic environment is a significant parasite assemblage structuring force, then sampling regimes may dictate results, thus, clouding our picture of parasite community ecology. The results of this study do not refute the conclusions of those who argue for interactive assemblages in species-poor hosts (Goater and Bush, 1988). However, the data suggest that these biotic interactions often may be masked by the effects of abiotic factors, especially in species-poor assemblages.

The relationships between diversity indicators and streamflow differ for the assemblages collected from the North Platte River and the South Platte River. The previous calendar year streamflow is negatively correlated with both the cur- rent calendar and water year streamflow and with the previous water year streamflow in the North Platte River. These correlations illustrate the variability of streamflow between years and within $1 \mathrm{yr}$ in the North Platte River. The South Platte River streamflow, however, remained positively correlated between the $2 \mathrm{yr}$, illustrating the dependency of streamflow in the South Platte River on natural forces. In the South Platte River the individual level assemblage descriptors were negatively correlated with streamflow, whereas the sample level descriptors showed a positive relationship with streamflow. In the North Platte River, however, all of the diversity values were negatively related to current year streamflow. These observations suggest that within-year variability in streamflow influences the stability and structure of parasite assemblage structure.

Both of the species frequency distributions that required an increased model sampling rate to mimic the field distributions corresponded to low streamflow months (North Platte River, May $1989,3.5 \mathrm{~m}^{3} / \mathrm{sec}$; South Platte River, August $1989,4.0 \mathrm{~m}^{3} / \mathrm{sec}$ ). As Janovy and Hardin (1988) pointed out, low water in a braided river creates excellent conditions for the survival of many intermediate hosts such as snails and oligochaetes. Evidently, the North Platte River conditions in May 1989 and the South Platte River conditions in August 1989 provided a situation in which hosts were exposed to infective stages more often than during the other collection periods.

\section{ACKNOWLEDGMENTS}

The authors thank A. Joern and L. Vescio for use of facilities at Cedar Point Biological Station. This work was supported in part by a grant from the Center for Great Plains Studies, an Ashton C. Cuckler Fellowship, and a Jesse A. Lee Award awarded to M.A.M. by the University of Nebraska.

\section{LITERATURE CITED}

BENTALl, R. (preparator). 1975. Hydrology, Nebraska Mid-State Division, Pick-Sloan Missouri Basin Program, and associated areas. University of $\mathrm{Ne}$ braska-Lincoln Conservation and Survey Division, Lincoln, Nebraska, 256 p.

Bush, A. O., AND J. C. Holmes. 1986. Intestinal helminths of lesser scaup ducks: Patterns of association. Canadian Journal of Zoology 64: 132-141.

GOATER, T., AND A. O. BUSH. 1988. Intestinal helminth communities in long-billed curlews: The importance of congeneric host-specialists. Holarctic Ecology 11: 140-145. 
HaIR, J. D., AND J. C. Holmes. 1975. The usefulness of measures of diversity, niche width and niche overlap in the analysis of helminth communities in water fowl. Acta Parasitologica Polonica 23: 253-269.

HoBerg, E. P. 1986. Evolution and historical biogeography of a parasite-host assemblage: Alcataeni sp. (Cyclophyllidea: Dilepididae) in Alcidae (Charadriiformes). Canadian Journal of Zoology 64: 2576-2589.

Holmes, J. C. 1961. Effects of concurrent infections on Hymenolepis diminuta (Cestoda) and Moniliformis dubius (Acanthocephala). I. General effects and comparison with crowding. Journal of Parasitology 47: 209-216.

JaNovy, J., JR., M. T. Ferdig, AND M. A. MCDowell. 1990. A model of dynamic behavior of a parasite species assemblage. Journal of Theoretical Biology 142: 517-519.

- AND E. L. HARDIN. 1987. Population dynamics of the parasites in Fundulus zebrinus in the Platte River of Nebraska. Journal of Parasitology 73: 689-696.

, AND - 1988. Diversity of the parasite assemblage of Fundulus zebrinus in the Platte Riv- er of Nebraska. Journal of Parasitology 74: 207213.

Kennedy, C. R., A. O. Bush, AND J. M. Aho. 1986. Patterns in helminth communities: Why are birds and fish different? Parasitology 93: 205-215.

Margolis, L., G. W. EsCh, J. C. Holmes, A. M. Kuris, AND G. A. SCHAD. 1982. The use of ecological terms in parasitology. Journal of Parasitology 68: 131-133.

MCAuliffe, J. R. 1984. Competition for space, disturbance, and the structure of a benthic stream community. Ecology 65: 894-908.

Pflieger, W. L. 1975. The fishes of Missouri. Missouri Department of Conservation, Jefferson City, Missouri, 343 p.

Price, P. W. 1980. Evolutionary biology of parasites. Princeton University Press, Princeton, New Jersey, $237 \mathrm{p}$.

- 1984. Communities of specialists: Vacant niches in ecological and evolutionary time. In Ecological communities: Conceptual issues and the evidence, D. R. Strong, Jr., D. Simberloff, L. G. Abele, and A. B. Thistle (eds.). Princeton University Press, Princeton, New Jersey, p. 51 1-523. 